\title{
Assessment of Child Sensitive Social Protection Programmes in Nepal
}

\author{
Bishwa Ratna Pun ${ }^{*}$, Gyanendra Kumar Shrestha ${ }^{2}$ \\ ${ }^{1}$ Save the Children International, Nepal \\ ${ }^{2}$ National Child Rights Council, Government of Nepal \\ *Corresponding author's email: bishwapun@gmail.com \\ DOI: https://doi.org/10.3126/jsp.v1i0.38211
}

\section{A R T I C L E I N F O}

Article history:

Received 11 Oct. 2020

Accepted 26 Nov. 2020

Keywords:

Child poverty and vulnerability

Child sensitive

Inclusiveness

Life cycle

Social accountability

Social protection

\section{A B S T R A C T}

Ctudies have shown that social protection programme can be $\checkmark$ detrimental to children if it is not designed and implemented in a proper way. Even programmes focusing on children can be countereffective and can leave a long-term adverse effect in the lives of children. This article aims to assess the children focused social protection programmes in Nepal from a child rights perspective with a specific consideration around the area of social assistance. This article adopts a Core Diagnostic Systems Assessment Instrument (CODI) tool and is primarily based on secondary data. Results show that the current social protection system, especially focused on children, in Nepal lacks several elements of child sensitivity such as 'adequacy', 'respect rights and dignity' in designing and implementation. Furthermore, though the Government of Nepal prioritise social assistance by channeling reasonable funding, the share of children focused programmes is relatively low. Any investment made on children currently, would result in their better future and the country at large. Thus, increasing social assistance targeting children will contribute to better child protection and eventually have significant development impacts. This will also be critical in ensuring the rights of children in general and vulnerable children in particular.

\section{Introduction}

Social protection is generally understood as a set of public actions aimed at addressing poverty, vulnerability and exclusion as well as provide means to cope with major risks throughout the life cycle (UNICEF, 2009:2).
According to the joint statement on advancing Child-Sensitive Social Protection (DFID et al., 2009), many social protection measures have already benefitted children, though they were not the primary beneficiaries. Rectification in the social protection policies and programmes targeting children can have huge positive 
changes in the lives of children (UNICEF, 2009). For instance, Child-Sensitive Social Protection (CSSP) policies and programmes address specific patterns of children's poverty and vulnerability in addition to recognising their long-term developmental benefits through a focused investment. It considers the voices and views of children and their families, seeks to maximise positive impacts on the lives of children while minimising any adverse impact on them. Moreover, CSSP is a proven approach in combating child poverty and vulnerability wherein it explicitly analyses and monitors the impact of social protection on children in various contexts including age, gender, and different types of vulnerability (Save the Children, 2015).

Children who grow up in an extreme poverty, are more likely to become malnourished, get sick, drop out from school, and get exposed to dangerous or exploitative environment (Save the Children, 2020). Social protection schemes targeting children could therefore play a pivotal role in averting these adverse situations. Investment on children through social protection schemes will not only benefit them but also their families, communities, and contribute to the overall development of the country. It is therefore imperative that CSSP schemes need to lay focus on children living with their families, also in addition to recognising and addressing the needs of children living in absence of their parents or guardians (Global Coalition to End Child Poverty, 2017; Save the Children, 2020).

There has been a rapid expansion of social protection schemes in Nepal, both in terms of its scale and coverage. Moreover, Nepal is regarded as one of the leading countries in terms of introducing such schemes. For instance, Nepal was the first country to introduce social pension, implement a set of nationally funded social protection schemes and is also in the process to finalising the National Framework for
Social Protection (IDS, 2016). However, such schemes have never been analysed from the perspective of child rights. Though 'child-focused' terms are highly used in the documents, it may not necessarily be childfocused. Moreover, child-sensitive social protection schemes and child-focused social protection are used interchangeably, though they are different in terms of their approach and objective. There is still a huge gap in terms of understanding the concepts on social protection programmes from the perspective of children welfare. Drawing on the review of literature this paper analyses the social protection programme from the perspective of rights of children in Nepal. Furthermore, it calls upon the government to review its social protection system, policies, and programme to make it more child sensitive in the Nepalese context.

\section{Methods and Materials}

The data was gathered from secondary sources that include laws, policies, plans, programmes, and reports of the government and development partners. Among the various types of assessment tools available, this paper adopts the Social Protection tool for assessing child sensitivity, developed by the United Nations International Children's Emergency Fund (UNICEF, 2014). This tool analyses the eleven dimensions of child sensitivity - expenditure, coverage and exclusion, acceptability, adequacy, appropriateness, adaptability, acceptability, transparency and accountability, responsibility and complementarity, participation, and impact. This paper is based on the following criteria and indicators to analyse child sensitivity in social protection of Nepal.

Inclusiveness: The social protection system should guarantee the children are protected at different stages of their lives. The goal is to 
eliminate coverage gap and inclusion of the poor and the most vulnerable children. It is considered as the indicator for inclusion of children from different stages of life cycle, inclusion of girls, ethnicity and children from poor families.

Impact and adequacy: Social protection programmes provide regular and predictable benefit and quality services that are adequate and sufficient to meet the needs of children. Social protection schemes have positive impact on child's wellbeing as measured by age, gender, and different forms of vulnerability. Indicators such as outcome in child survival, nutrition and education available and benefit size for adequacy are considered for assessing the impact and adequacy.

Appropriateness:: At the policy level, it means the use of evidence and formation of clear and realistic targets and time frames to better address social protection needs of children. It is focused on acceptance of the social protection provisions by the target groups.

Respect for rights and dignity: The system is transparent and accountable for instance, through effective and efficient grievance and complaint mechanisms, ensure that the procedures are accessible to children. Social protection programmes and benefits are in line with human rights standards and principles, including participation by children in design, delivery and ensuring that the system doesn't cause harm to the children. It is considered to analyse the mechanism of social accountability such as child consultation, interface platforms, and grievance mechanism among others.

Governance and institutional capacity: Child sensitive social protection system requires a sufficient institutional capacity, and clear internal rules, regulation, reporting mechanism, and operating procedures. For its assessment, data management system, reporting system and human resource capacity are considered.

Financial and fiscal sustainability: The level and quality of government spending on social protection, including direct and indirect expenditure is aligned with the needs of children. For this, it assesses the budget allocation for children, and the fiscal sustainability.

Coherence and integration: The set of existing programmes are internally coherent in that they complement each other with regard to addressing the most serious child deprivation. It assesses the coordination between the responsible ministries and departments (horizontal), among local government, provincial and federal government (vertical).

Responsiveness: The system has the flexibility to adjust/adopt in response to the changing needs of children and socio-economic crises, including in humanitarian crisis. Responsiveness requires regular monitoring and periodic evaluation for these development as well as of the social protection programmes and schemes. In the Monitoring \& Evaluation (M\&E) system, flexibility adjusts and adapts to address the needs and situation of the children. It is focused to assess the linkage of social protection with disaster risk reduction policy, and its flexibility in terms of social protection system.

\section{Resultts and Discussion}

\subsection{Overview of social protection initiatives and child sensitive social protection in global context}

The social protection programme was first introduced in Germany in 1880's targeting the health insurance of sick workers following which it was adopted by other countries. For instance, France started with unemployment allowance system from 1905 followed by 
the United Kingdom which initiated the health insurance, unemployment allowance and senior citizen insurance or allowance programme in 1911. Likewise, the then Soviet Union introduced the comprehensive social protection arrangements in 1922, while the United States started the unemployment, senior citizen and retired personnel allowance and insurance (SPCSN, 2016). To date, social protection programmes are in implementation in many countries across the globe.

The issue of social protection has been addressed by the United Nations Universal Declaration of Human Rights in 1948, and various other declarations so far cover social protection issues for individuals and groups of different ages and backgrounds. Article 22 of the Universal Declaration on Human Rights, 1948 guarantees that everyone, 'as a member of the society, has the right to social protection and is entitled to realisation, through national effort and international cooperation and in accordance with the organisation and resources of each State, of the economic, social and cultural rights indispensable for his/her dignity and the free development of his/her personality'. Likewise, Article 25 (2) is specific to children and states that 'motherhood and childhood are entitled to special care and assistance'. The Social protection (Minimum Standards) Convention, 1952 (ILO Convention No. 102), which came into effect from 27 April 1957 , is the only international instrument that establishes worldwide-agreed minimum standards for all nine segments of social protection (ILO, 1952). The United Nations Convention on the Rights of the Child, 1989 (UNCRC) recognises the child as a bearer of economic, social and cultural rights such as the right to education, to health care, to adequate standard of living; and to benefit from social protection (UNCRC, 1989). UNCRC also requires states to support families when they are unable to take care of their children.
Though children are usually economically dependent upon adults, and when the later are unable to support, either because they are unable to find employment or because their circumstances (illness, disability, child bearing, old age and so on) prevent them from working, then the state has an obligation to ensure that children have some form of financial support, either paid directly to the child or via a responsible adult (OHCHR, 1990). Similarly, international organisations like Save the Children have their own set of definition on social protection where they define it as 'a set of policies, programmes and system that help poor and vulnerable individuals and households to reduce their economic and social vulnerabilities, improve their ability to cope with risks and shocks and, enhance their social status and human rights (Save the Children, 2015:1). Furthermore, it has categorised social protection as social assistance, including cash transfers, in-kind transfers or a combination, social insurance, such as unemployment benefits, health insurance,- and relevant national legislation, policies and regulations, such as maternity policy (Save the Children, 2015:1).

Likewise, UNICEF has its own definition on social protection where it is defined as a '...set of public and private policies and programmes aimed at preventing, reducing and eliminating the economic and social vulnerabilities to poverty and deprivation' by supporting the development of integrated systems addressing age and gender specific issues by means of a mix of different social protection interventions and in coordination with other sectoral policies. This definition takes into account four main components of social protection such as, social transfers, programmes to ensure access to services, social support and care provision, and legislation and policy reforms.

UNICEF's work on CSSP starts from publication of joint statement for advancing child sensitive social protection 
in 2009. UNICEF developed its first global social protection framework in 2012 and subsequently updated it in 2016. The framework is based on thrust of principles of the CSSP joint statement and UNCRC. UNICEF has been focusing its CSSP work in middle and low- income countries. 'The conceptual foundations of UNICEF's approach to social protection remain unwavering and highlights it as 'a rights-based approach towards universal social protection as set out in the Universal Declaration of Human Rights and UNCRC' (UNICEF, 2019:1). In Nepal, UNICEF's work on social protection is aiming at strengthening the social protection system in both development and humanitarian context, providing technical assistance to scale up the child grant at federal level set up until it reaches to all children under five years of age, improve the implementation and delivery of the child grant through improving enrollment and delivery process. In addition, UNICEF is scaling-up its efforts on shock responsive social protection. Top-up Cash Transfer programme during the 2015 earthquake is one of the very well-known examples of it.

Save the Children started working on CSSP since 2011 from South Asia (Nepal, India, and Bangladesh), and is rapidly expanding in low-income countries across Asia and Africa. Moreover, it has accepted CSSP as one of its major strategies to reduce child poverty and has adopted six approaches for its advancement. First, strengthening child sensitivity in existing social protection programme to boost child nutrition and development outcome, and to reduce child labor (in Nepal, India, Bangladesh, Philippines, Zambia). Second, piloting new child sensitive social protection programmes using evidence-based approach (in Myanmar, Nigeria, Cambodia, Guatemala, Somalia, Burkina Faso, Malawi, DRC, and India). Third, improving access to existing government social protection among the most marginalised and deprived, through strengthening inclusion and accountability mechanisms (in Nepal, India, Philippines, Bangladesh, and Nigeria). Fourth, advocate for increasing government's investment in child sensitive social protection for expanded coverage (Nigeria, Myanmar, Somalia, Nepal, and Burkina Faso). Fifth, support climate change adaptation and shock responsiveness of social protection, with a focus on the need of children and their caregivers (in Malawi and other multi-countries). Finally, it links CSSP with humanitarian cash and voucher assistance (Save the Children, 2020).

\subsection{Child poverty and vulnerability situation in Nepal}

It is globally agreed that impoverishment among children is not merely limited to monetary terms. The United Nations General Assembly has adopted a new definition for child poverty that recognises multidimensional deprivation of children. The United Nations General Assembly defines child poverty as

Children living in poverty are deprived of nutrition, water and sanitation facilities, access to basic health-care services, shelter, education, participation and protection, and that while a severe lack of goods and services hurts every human being, it is most threatening and harmful to children, leaving them unable to enjoy their rights, to reach their full potential and to participate as full members of the society (UNICEF, 2007).

Deprivation can change or overlap as a child grows depending upon the context. For example, nutrition deprivation could be more intense for early stage while education and protection deprivation would be more challenging in adolescence stage. Millions of children in Nepal are highly vulnerable and deprived of basic needs. Around 28.6 per cent of people are multi-dimensionally poor (NPC, 2018:1), among them, 34 per cent are children below the age of 15 (New ERA, 2017). 
Further, the Multi-dimension Poverty Index (MPI) report shows that children below age of 10 represent the poorest age subgroup of Nepal (NPC, 2018:17). The current status of key indicators related to children is presented in Table 1.

\subsection{Overview of social protection initiatives to address child poverty and vulnerability in Nepalese context}

\subsubsection{Evolution of social protection in Nepal}

Social protection initiative commenced in the year 1935 with an effort to provide a

Table 1: Status of key indicators related to children, 2019/20

\begin{tabular}{|c|c|c|}
\hline Age group & Indicator & $\begin{array}{c}\text { Status } \\
(2019 / 20) \\
\end{array}$ \\
\hline $0-2$ yrs. & Full immunisation coverage- $\%$ & 70.2 \\
\hline $0-5$ yrs. & Child mortality rate/1000 live birth & 28 \\
\hline $0-5$ yrs. & Underweight Prevalence (Nutrition) - \% & 24.3 \\
\hline $0-5$ yrs. & Stunting Prevalence (Nutrition) - \% & 31.5 \\
\hline $0-5$ yrs. & Severe stunting Prevalence- $\%$ & 11.8 \\
\hline $0-5$ yrs. & Wasting Prevalence - \% & 12 \\
\hline $0-5$ yrs. & Severe Wasting Prevalence - \% & 2.9 \\
\hline $0-2$ yrs. & Children ever breastfed- \% & 98.7 \\
\hline $0-2$ yrs. & Early initiation of breastfeeding- $\%$ & 41.7 \\
\hline $0-6$ months & Exclusive breastfeeding under 6 months- $\%$ & 62.1 \\
\hline 6- 23months & Minimum acceptable diet- $\%$ & 31.0 \\
\hline 6- 23months & Minimum dietary diversity - $\%$ & 39.7 \\
\hline 6- 23 months & Minimum meal frequency- $\%$ & 68.9 \\
\hline $2-5$ yrs. & Early stimulation and responsive care- $\%$ & 76.9 \\
\hline $3-5$ yrs. & Attendance to early childhood education- $\%$ & 61.9 \\
\hline Under 10 yrs. & Net attendance ratio (adjusted) for grade 1- 5- \% & 74.5 \\
\hline Under 12 yrs. & Out of School rate (ECD to lower secondary) - \% & 5.6 \\
\hline Under 5 yrs. & Birth registration $-\%$ & 77.2 \\
\hline Under 14 yrs. & Violent discipline- $\%$ & 82 \\
\hline Under 18 yrs. & Child marriage- $\%$ & 22.7 \\
\hline $6-17$ yrs. & Children engaged in Labor - \% & 37.4 \\
\hline Under 18 yrs. & $\begin{array}{l}\text { Children's living arrangements (living with neither } \\
\text { biological parents) - \% }\end{array}$ & 5.3 \\
\hline Under 18 yrs. & Prevalence of children with one or both parents dead- $\%$ & 4.2 \\
\hline Under 18 yrs. & Children with at least one parent living abroad- \% & 20.4 \\
\hline Under 18 yrs. & Children with functional difficulties - $\%$ & 10.6 \\
\hline Under 18 yrs. & HHs having housing (Flooring and Roofing) - \% & 67.3 \\
\hline Under 18 yrs. & HHs use of improved drinking water sources- $\%$ & 97.1 \\
\hline Under 18 yrs. & HHs availability of drinking- $\%$ & 80.3 \\
\hline Under 18 yrs. & HHs handwashing facility with water and soap- \% & 80.7 \\
\hline Under 18 & Use of improved sanitation facilities- $\%$ & 94.5 \\
\hline
\end{tabular}

Source: CBS and MICS, 2019. 
lump sum annual amount to the wounded Nepali soldiers returning from World War I. The social protection measures have been included especially from the Sixth Plan (1980/81-1984/85) of the Government of Nepal, primarily focusing on cash transfers to address the issues of poor and marginalised groups. So far, social protection programmes for children and other vulnerable groups have been significantly improved and expanded. Coming to date, there are broadly two kinds of social protection programmes - contributory and non-contributory, as well as cash and kind transfer and services. The programmes can be basically divided into three groups -

a. Social insurance: This includes pensions, allowances, saving funds, various insurance schemes and other facilities especially targeted for the employees from different sectors. The insurance is constituted through contributions from targeted people.

b. Social assistance: This includes cash transfers, in-kind assistance, free education, health and nutrition, and other services including emergencies - in noncontributory basis.

c. Labor market facilitation: This includes provision of skills and entrepreneurship trainings, food for work, development of rural infrastructure, one family one employment scheme, prevention of child labor, youth self-employment programme, grants for productive and innovation activities.

\subsubsection{Social protection programmes and its legal and policy framework in Nepal}

The Constitution of Nepal, 2015 guarantees the right to equality, and states social protection as fundamental rights (Government of Nepal, 2015:103-105). It clearly states that 'there will be no discrimination on the grounds of origin, religion, race, caste, tribe, sex, physical conditions, disability, health condition, matrimonial status, pregnancy, economic condition, language or geographical region, or ideology or any other such grounds' rights (Government of Nepal, 2015: 97, article 18). Nevertheless, it permits to make positive discrimination and special provisions to children among other needy sections of the society. Apart from the specific right to social protection, the Constitution has also guaranteed the right to free and compulsory basic education and free education up to secondary level; the right to free higher education to physically impaired and citizens who are economically poor; the right to live in clean and healthy environment; the right to emergency health care; the right to access to clean water and hygiene; the right to food; the right to appropriate housing; the right to safe motherhood and reproductive health; the right to compensation for the victim of violence and discrimination. Among others, Children's Act, 2018; Social Protection Act, 2018; Compulsory and Free Education Act, 2018; and Public Health Service Act, 2018, all have social protection provisions for children.

The Government of Nepal has given high priority for social protection programme. The Fifteen Plan (2019/20-2013/24) has clearly highlighted nation's vision, mission, goals and strategies in terms of prioritising the social protection programme. Likewise, the Child Act 2018 has identified over 18 categories of vulnerable children required of special protection from the state that includes orphan children, child labor, children in conflict of law, disabled, abandoned and unaccompanied, drug addicts, HIV/AIDS infected and affected, children affected by conflicts and so on. The government has initiated cash transfer for orphan children and declaring 'street children free' country from 2020 onwards.

The Government of Nepal has highlighted the issues of social protection programme in the budget speech in the fiscal year 2020/21. It includes gradual improvement 
of social protection programme in the life cycle, in addition to making it compulsory and universal, focusing for children and other poor and vulnerable people. A total of Nepalese Rupees (NRs) 3.76 billion has been allocated for this purpose which accounts to 6.6 per cent of the total budget. It is estimated that about 1.3 million children are benefited through this programme.

\subsubsection{Children related social protection programmes in Nepal}

The Government of Nepal has given high priority for value of investment in the early stage of a child, especially during the first 1000 days of the early childhood development. The government recognises the need for such investments to enable children to reach their full potential and contribute to long-term growth and prosperity of the nation (EPRI, 2020). The Government of Nepal has adopted the life cycle approach for social protection (Table 2). Within the three dimensions of the social protection programme, children in Nepal are mostly benefitted from social assistance and social services. It covers free education, health and nutrition programme at large, and child grant, scholarships, mid-day meal birth registration incentives in specific. Health and nutrition related programmes are presented in Table 2.

There are some categories of children who need to stay in the hostel for the purpose

Table 2: Child health and nutrition related social protection programme in Nepal

\begin{tabular}{|c|c|c|}
\hline $\begin{array}{l}\text { Life cycle } \\
\text { stages }\end{array}$ & Scheme & Benefit size \\
\hline $0-5$ yrs. & $\begin{array}{l}\text { Child grant: Universal in } 14 \text { districts * and } \\
\text { for Dalit children in rest of the country }\end{array}$ & NRs. 400 per child per month \\
\hline $0-5$ yrs. & $\begin{array}{l}\text { Birth registration incentive for Dalit } \\
\text { children }\end{array}$ & NRs. 1000 per child (One-time) \\
\hline $0-5$ yrs. & $\begin{array}{l}\text { Multi-sectoral national nutrition programme } \\
\text { in } 25 \text { districts }\end{array}$ & $\begin{array}{l}\text { Super flour and complementary } \\
\text { food distribution and other } \\
\text { Nutrition services }\end{array}$ \\
\hline $0-5$ yrs. & $\begin{array}{l}\text { Nutrition rehabilitation center for children } \\
\text { suffering from severe malnutrition }\end{array}$ & $\begin{array}{l}\text { Free health checkup, nutrition } \\
\text { service and free food for } \\
\text { children and care- taker }\end{array}$ \\
\hline $0-5$ yrs. & Immunisations (11 types) & Free immunisations \\
\hline $0-5$ yrs. & A separate dedicated hospital at federal level & $\begin{array}{l}\text { Free treatment for newborn and } \\
\text { children from poor families }\end{array}$ \\
\hline $0-15$ yrs. & $\begin{array}{l}\text { Special waiver for children who are } \\
\text { suffering from serious heart diseases }\end{array}$ & \\
\hline $0-17$ yrs. & Free deworming & \\
\hline $\begin{array}{l}3-10(\mathrm{ECD}- \\
\text { grade } 5)\end{array}$ & Mid - day meal in Karnali and 14 districts** & Free day meal of NRs. 15 \\
\hline 4-5 yrs. & Early Childhood Development Programme & Free education in 3412 centers \\
\hline \multicolumn{3}{|c|}{$\begin{array}{l}\text { * Dolpa,Humla,Jumla,Kalikot, Mugu, Rautahat, Achham, Bajhang, Mahottari, Jajarkot, Sarlahi, Dolti, } \\
\text { Bajura and Siraha }\end{array}$} \\
\hline $\begin{array}{l}\text { ** Karnali (1 } \\
\text { Nabalpara }\end{array}$ & $\begin{array}{l}\text { ba,Humla,Jumla,Kalikot, Mugu)Kailali, Bardiya, } \\
\text { Bara, Dhading, Sindhupalchowk, Rasuwa, Siraha, Sc }\end{array}$ & $\begin{array}{l}\text { Dang, Pyuthan, Rolpa, Kapilbastu, } \\
\text { ptari and Sunsari. }\end{array}$ \\
\hline
\end{tabular}


of their studies which can be attributed to several reasons. For example, some students, students, who stay with their own family. So, the Government of Nepal has two types of

Table 3: Residential scholarship provisions for students

\begin{tabular}{|c|c|c|c|}
\hline S.N. & $\begin{array}{l}\text { Life cycle } \\
\text { stages }\end{array}$ & Scheme & Benefit size \\
\hline 1 & $\begin{array}{l}6-14 \text { years } \\
(\text { Grade } 1-8)\end{array}$ & $\begin{array}{l}\text { Scholarships for children with } \\
\text { disability who stay in hostel }\end{array}$ & $\begin{array}{l}\text { NRs. } 4,000 \text { per child per month (NRs. } \\
40,000 \text { annual) }+ \text { Hygiene cost NRs. } \\
500 \text { per child per month + (NRs. } 5,000\end{array}$ \\
\hline 2 & $\begin{array}{l}12-17 \text { years } \\
(\text { Grade } 6-12)\end{array}$ & $\begin{array}{l}\text { Scholarships for free girl child labors } \\
\text { (Kamlari) who stay in hostel }\end{array}$ & $\begin{array}{l}\text { NRs. } 4,000 \text { per child per month (NRs. } \\
40,000 \text { annual) }+ \text { Hygiene cost NRs. } \\
500 \text { per child per month + (NRs. } 5.000 \\
\text { annual) }\end{array}$ \\
\hline 3 & $\begin{array}{l}12-17 \text { years } \\
(\text { Grade } 6-12)\end{array}$ & $\begin{array}{l}\text { Scholarships for children from } \\
\text { remote districts (Mustang, Humla } \\
\text { and Jumla) who stay in Himali hostel }\end{array}$ & $\begin{array}{l}\text { NRs. } 1800 \text { per } 4,000 \text { per child per month } \\
\text { (NRs. } 40,000 \text { annual) + Hygiene cost } \\
\text { NRs. } 500 \text { per child per month }+ \text { (NRs. } \\
\text { 5,000 annual) }\end{array}$ \\
\hline 4 & $\begin{array}{l}15-17 \text { years } \\
(\text { Grade } 9-12)\end{array}$ & $\begin{array}{l}\text { Scholarship for girls from } \\
\text { Mountains* and endangered ethnic } \\
\text { groups** who stay in hostel }\end{array}$ & $\begin{array}{l}\text { NRs. } 4,000 \text { per child per month (NRs. } \\
40,000 \text { annual) }+ \text { Hygiene cost NRs. } 500 \\
\text { per child per month (NRs. } 5000 \text { annual) }\end{array}$ \\
\hline 5 & $\begin{array}{l}\text { 6-15 years } \\
\text { (Grade 6-10) }\end{array}$ & $\begin{array}{l}\text { Scholarship for children from } \\
\text { endangered ethnic groups from } \\
\text { Sankhuwasabha, Rasuwa, Taplejung, } \\
\text { Gorkha, Jumla and Darchula districts } \\
\text { who stay in hostel }\end{array}$ & $\begin{array}{l}\text { NRs. } 4,000 \text { per child per month (NRs. } \\
40,000\end{array}$ \\
\hline 6 & $\begin{array}{l}\text { 14- } 16 \text { years } \\
\text { (Grade } 9-10)\end{array}$ & $\begin{array}{l}\text { Scholarship for children from very } \\
\text { poor families who are graduated } \\
\text { grade } 8 \text { but could join grade } 9 \text { who } \\
\text { need stay in hostel }\end{array}$ & $\begin{array}{l}\text { NRs. } 4000 \text { per child per month (NRs. } \\
40,000 \text { annual) + Hygiene cost NRs. } 500 \\
\text { per child per month (NRs. } 5000 \text { annual) }\end{array}$ \\
\hline
\end{tabular}

Source: Save the Children, 2017

* Ilam, Okhaldhunga, Mahottari, Sarlahi, Nuwakot, Palpa, Kapilbastu, Dang, Baglung, Rolpa, Dolpa, Kailali, Jajarkot, Jumla, Humla, Doti, Baitadi, Dolakha, Makawanpur and Rautahat districts.

** Chepang, Raute, Kusunda, Hayu, Bankariya, Rajhi, Majhi, Kisan, Lepcha, Thami, Danuwar, Baram, Satar/ Santhyal, Jhangad, Kubaudiya, Meche, Surel, Thudam, Sichar, Lahimi (Singsama Bhote) and Dhanak.

who come from high mountain areas, are not able to attend secondary and higher secondary education since it takes days to reach the schools. So, they need to stay in hostels based in schools or close to it. Similarly, some children with disability also need to stay in the hostel since their families cannot take them to school every day. Staying in the hostel costs higher in comparison to other scholarships - residential and non- residential - to address the different types of issues that children face in Nepal. Table 3 presents residential scholarship provided to children from different vulnerability categories, who stay in hostel for education.

According to the Ministry of Education, this programme contributed to increase the 
Table 4: Scholarship for children from different vulnerability categories who is living with their families

\begin{tabular}{|c|c|c|c|}
\hline S.N. & $\begin{array}{c}\text { Life Cycle } \\
\text { Stages }\end{array}$ & Scheme & Benefit size \\
\hline 1 & $\begin{array}{l}\text { 6-14 years } \\
\text { (grade } 1 \\
-8)\end{array}$ & $\begin{array}{l}\text { Scholarships for children with } \\
\text { disability who need to support to } \\
\text { travel to school }\end{array}$ & $\begin{array}{l}\text { NRs. } 500 \text { per child per month for } 10 \text { months, (NRs. } \\
5,000 \text { annual) + Supporting equipment cost NRs. } \\
300 \text { per month for } 10 \text { months (NRS. } 3,000 \text { annual) }\end{array}$ \\
\hline 2 & $0-17$ & $\begin{array}{l}\text { Scholarships for children of } \\
\text { martyrs }\end{array}$ & $\begin{array}{l}\text { NRs. } 12,000 \text { annual per child for grade } 1-5 \\
\text { NRs. } 18,000 \text { annual per child for Grade } 6-8 \text { and } \\
\text { NRs. } 24,000 \text { annual per child for grade } 9-12\end{array}$ \\
\hline 3 & $0-17$ & $\begin{array}{l}\text { Scholarships for children whose } \\
\text { mother or father is killed in } \\
\text { armed conflict }\end{array}$ & $\begin{array}{l}\text { NRs. } 10,000 \text { annual per child for grade } 1-5 \\
\text { NRs. } 12,000 \text { annual per child for Grade } 6-8 \\
\text { NRs. } 14,000 \text { annual per child for grade } 9-10 \\
\text { NRs. } 16,000 \text { annual per child for grade } 11-12\end{array}$ \\
\hline 4 & $0-17$ & $\begin{array}{l}\text { Scholarships for children whose } \\
\text { mother or father has disable by } \\
\text { armed conflict }\end{array}$ & $\begin{array}{l}\text { NRs. 5,000 annual per child for grade } 1-5 \\
\text { NRs. } 6,000 \text { annual per child for Grade } 6-8 \\
\text { NRs. } 7,000 \text { annual per child for grade } 9-10 \\
\text { NRs. } 8,000 \text { annual per child for grade } 11-12 \\
\end{array}$ \\
\hline 5 & 6- 17 & $\begin{array}{l}\text { Scholarships for free girl child } \\
\text { labors (Kamlari) }\end{array}$ & $\begin{array}{l}\text { NRs. } 1,500 \text { annual per child for grade } 1-8 \\
\text { NRs. } 1,800 \text { annual per child for Grade } 9-10 \\
\text { NRs. } 5,000 \text { annual per child for grade } 11-12 \\
\text { NRs. } 10,000 \text { annual per child for higher education }\end{array}$ \\
\hline 6 & $15-17$ & $\begin{array}{l}\text { SEE bridge course support for } \\
\text { Dalit children }\end{array}$ & \\
\hline 7 & $\begin{array}{l}14-15 \\
\text { Grade } 8-9\end{array}$ & $\begin{array}{l}\text { Scholarship for children who are } \\
\text { from economically very poor } \\
\text { families support for Dalit children }\end{array}$ & NRs. 1,700 one-time support \\
\hline 8 & $\begin{array}{l}14-15 \\
\text { Grade } 8-9\end{array}$ & $\begin{array}{l}\text { Scholarship for children who are } \\
\text { from endangered ethnic groups, } \\
\text { free laborers, ethnic minorities, } \\
\text { Haliya, Charuwa and Badi } \\
\text { communities }\end{array}$ & NRs. 1,700 one-time support \\
\hline 9 & $0-17$ years & $\begin{array}{l}\text { Scholarship for girls from Karnali } \\
\text { and very poor families }\end{array}$ & $\begin{array}{l}\text { Stationaries or school dress support } \\
\text { NRs. } 1,000 \text { for grade } 1-5 \text { and NRs. } 1,500 \text { for grade } \\
6-8 \text { per girl child one time support }\end{array}$ \\
\hline 10 & $6-14$ years & $\begin{array}{l}\text { Scholarship for children who are } \\
\text { Dalits, poor families, conflict } \\
\text { affected }\end{array}$ & $\begin{array}{l}\text { Stationaries or school dress support } \\
\text { NRs. } 1,000 \text { for grade } 1-5 \text { and NRs. } 1500 \text { for grade } \\
6-8 \text { per girl child one time support }\end{array}$ \\
\hline 11 & $0-17$ years. & $\begin{array}{l}\text { Scholarship for children from } 22 \\
\text { ethnic groups, free laborers, Badi, } \\
\text { Haliya, Charuwa who are Dalits, } \\
\text { poor families, Conflict affected }\end{array}$ & NRs. $400-600$ \\
\hline 12 & $\begin{array}{l}14-15 \\
\text { Grade 8-9 } \\
\end{array}$ & $\begin{array}{l}\text { Ramnarayan Mishra special } \\
\text { scholarship }\end{array}$ & NA \\
\hline 13 & $\begin{array}{l}\text { 6-17 (Grade } \\
1-10) \\
\end{array}$ & $\begin{array}{l}\text { Education material support for } \\
\text { children who have not received } \\
\text { any scholarship, as per need }\end{array}$ & NRs. 1,000 \\
\hline 14 & $\begin{array}{l}6-17 \text { (Grade } \\
1-10)\end{array}$ & Free textbook distribution & \\
\hline 15 & $\begin{array}{l}6-13 \\
(\text { Grade 1-8) }\end{array}$ & Dalit Scholarship & $\begin{array}{l}\text { Terai - NRs. } 450 \text {, Hill- NRs. 525, Mountain-NRs. } \\
600 \text { per child per year }\end{array}$ \\
\hline 16 & $\begin{array}{l}6-13 \\
(\text { Grade } 1-8)\end{array}$ & Girls Scholarship & $\begin{array}{l}\text { Terai - NRs. } 450 \text {, Hill- NRs. } 525 \text {, Mountain-NRs. } \\
600 \text { per child per year }\end{array}$ \\
\hline
\end{tabular}

Source: Save the Children, 2017. 
access and retention of targeted students in school education. The government has allocated NRs. 2.70 billion for various scholarships in the fiscal year 2020/21. Besides the residential scholarship, the government has been providing various nonresidential scholarships for girls, children with disabilities, children of martyrs, children affected by armed conflict, girl child laborers (Kamalari), children of Dalit and marginalised groups and child laborers. Table 4 presents non-residential scholarships schemes for children from different vulnerability categories, and those living with their families.

Millions of targeted children have benefited from these scholarships in addition to contributing to bring children to schools and continue with their school education. In academic year 2016, 718,471 Dalit students in grades 1-8 and 92,229 Dalit students in grades 9-10 were supported for scholarships. Likewise, 28,033 students with disability in grades 1-8 and 3,754 students with disability in grades 9-10 benefitted from the scholarship programme. A total of $2,193,695$ female students across the country and 11,351 female students in Karnali region benefitted from girl's scholarship programme. Similarly, 103,520 students from targeted populations at secondary level received the scholarship. Furthermore, 17,407 targeted students studying at the secondary level were awarded with the Ramnarayan Mishra special scholarship (Ministry of Education, 2016).

\subsection{Assessment of social protection programme from child sensitive perspective}

Many social protection measures - ranging from pensions to unemployment insurance - have already benefited children without explicitly targeting them (UNICEF et al., 2009). However, it is more important to assess the programmes from a child rights perspective, if they are meant to be child sensitive. The child sensitive social protection programmes of Nepal is assessed based on the following indicators.

\subsubsection{Inclusiveness}

The social protection system should guarantee the children are protected at different stages of their lives. The goal is to eliminate coverage gap and inclusion of the poor and the most vulnerable children.

The Government of Nepal has given emphasis to the investment in early stage of children for improvement of their nutritional status that can have long lasting effect in their future. Investment in their early stage, especially under five, has noticeably contributed to improvement of child survival rate and to reduce malnutrition in Nepal. Child mortality rate/1000 livebirth has been decreased from 162 in 1991/92 to 28 in $2019 / 20$, infant mortality rate/1000 livebirth from 108 to 25 , and neo-natal mortality rate /1000 livebirth from 50 to 16 (National Child Right Council, 2019:21-22). Child undernutrition rates substantially declined over the past two decades.

The prevalence of undernourishment has improved to a large extent from 36.1 per cent of population in 2015 to 8.7 per cent in 2019. Likewise, the percentage of underweight children (among 6-59 months) in Nepal was 43 per cent in 2000, 29 per cent in 2015 with a further drop to 27 per cent in 2016 and it has decreased to 24.3 per cent in 2019. Nepal has the target of reducing this to 9 per cent by 2030. Similarly, the prevalence of stunting among children under five years of age was 36 per cent in 2016 and has dropped to 31.6 per cent in 2019 (NPC, 2020:30-31).

During the same period, child wasting (low weight for height) declined from 15 per cent to 10 per cent (New ERA, 2017:225). The Government of Nepal has also allocated substantial resources to cover the adolescent 
stages through different scholarship schemes and has attempted to cover the most vulnerable children with disability and exchild labor (Kamlari) as well as children from the most remote and geographically challenging areas. Investment in scholarships has been a success in terms of improving school enrollment in the last few decades. Net enrollment rate at the primary level has increased from 64 per cent in 1991/92 to 97.1 per cent in 2019/20. Likewise, girl's ratio at primary level has increased from 0.56 to 0.98 and the ratio between grade 1-12 reached to 1.01 in 2019/20. There has been a significant improvement in the retention rate of school education. However, about 3 per cent children are deprived of primary education followed by 31 per cent from secondary education (grade 9-10) and 52.4 per cent from grade 11-12. Children below the age of five have left from birth registration, and about 30 per cent children have not received complete immunisations.

In regards to the coverage, most of the programmes are fragmented and limited. The Mid-day Meal scheme is limited to few schools of limited districts. Similarly, child grant does consider pregnancy period, which is the most sensitive phase for the development of child's brain. Almost nutrition focused programmes are geographically targeted and exclude thousands of children living in urban poverty. Coverage of child grant in comparison to other social protection schemes is very low. Still, 52.2 per cent of eligible children are not registered for child grant (Oxford Policy Management, 2020). The 'children who needs special protection from state' as defined by the Child Act 2018 are excluded from the social protection programme of the state such as orphan children, street children, HIV AIDs affected children and so on.

\subsubsection{Impact and adequacy}

Social protection programmes provide regular and predictable benefit and quality services that are adequate and sufficient to meet the needs of the children. Social protection schemes have positive impact of child wellbeing as measured by age, gender, different form of vulnerability.

Nepal's social protection system can be considered to have positively influenced children's lives in areas of poverty, nutrition and health followed by bringing positive changes with respect to education and child care (Institute of Development Studies, 2016). Further, social protection allowances are seen as regular and secure source of income at the household level (CEDA, 2017). Very recently, the Economic Policy Research Institute (EPRI) conducted an early impact evaluation on Nepal Child Grant Programme that had highly encouraging impacts among the lives of the children under five years. The evaluation shows that Child Grant Programme has the potential to contribute towards human capital accumulation and overall wellbeing of children living in beneficiary households. The quantitative data shows progress towards impact through three main pathways (i) improvements in acute and current malnutrition, (ii) direct investments in age-appropriate stimulation, and (iii) improvements in the status of women within households. The qualitative data support these findings through evidences on better nutritional knowledge and improved feeding practices (purchasing more, diverse and nutritious foods), improved uptake of health care services for basic illnesses, uptake of education (ECD), and access to essential and short-term credit (EPRI, 2020).

However, in case of benefit size or adequacy, there is a huge variance among different schemes. The social assistance allowances that the Federal Government provides are calculated arbitrarily. The allowance values promised to different groups vary from NRs. 400 to NRs. 2000 per month (Niti Foundation, 2019). Institutional 
delivery scheme is also not enough to address the real needs of pregnant women. Similarly, NRs. 400 for child grant is also too low in comparison to other adult scheme and is not enough to cover actual needs of the children belonging to very poor families (KARRAK India and Valley Research Groups Nepal, 2010). The values of the social assistance allowances that the Federal Government provides to different groups vary considerably and arbitrarily, and neither correspond to the nationally nor internationally defined standards required for fulfilling basic needs. The Federal Government should define the values based on objective in a way that would meet the beneficiaries' basic needs (Niti Foundation, 2019).

\subsubsection{Appropriateness}

The system's overall arrangement to respond to the needs, norms and context of children. At the policy level, it means the use of evidences and formation of clear and realistic targets and time frames to better address social protection needs of children

There is no evidence as of yet to show that the social protection programmes have been rejected by the beneficiaries in Nepal. Even in cases where the programmes have relatively low coverage, it may not be attributed to un-willingness or un-appropriateness. There are other reasons however, such as lack of awareness, lack of legal documents, and complicated procedures among others that have resulted in low coverage of such programmes. Though the coverage is yet to be improved, there is an increasing trend in the number of social protection beneficiaries every year. This is also another indicator that shows the social protection programme as an appropriate and relevant way to respond to the needs, norms and context of children and their families in Nepal. However, comprehensive study or analysis ahead of designing such programmes in order to know the need of target groups, cultural norms and values of the target groups, infrastructure for payment mode, is largely missing. Most of the time, decision on new scheme is made on an ad hoc basis. Many programmes in recent years have been introduced haphazardly through budgetary statements without sufficient preparatory work. The nature and coverage of these programmes indicate that many of them have been guided by piecemeal or appeasement approach rather than by a wellthought-out social protection policy (Khanal, 2014)

\subsubsection{Respect for rights and dignity}

The system is transparent and accountable for instance through effective and efficient grievance and complaint mechanisms which are accessible to children. Social protection programme and, benefits are in line with human rights standards and principles, including participation by children in design, delivery and ensuring the system doesn't cause harm to children

There is a strong need for social accountability mechanisms in this sector to be adapted in ways that serve to empower the poor and vulnerable beneficiaries (Ayliffe et al., 2017). This is more applicable in case of children who are dependent on adults and lack capacity to voice their concerns mainly because of their age. Social accountability is an approach where citizens are the key actors in terms of building accountability. More specifically, it refers to 'the extent and capacity of citizens to hold the state and service providers accountable and make them responsive to the needs of citizens and beneficiaries' (Ayliffe et al., 2017). Social accountability is important for social protection for at least three reasons: i) it helps programmes function effectively by reducing error, fraud and corruption; ensuring that social protection recipients receive the right amount of cash regularly, reliably and accessibly; and helping to improve policy design; ii) social 
accountability also contributes to broader efforts to strengthen state-society relations; and, iii) finally, having a voice on issues that affect our lives is central to our dignity and self-worth and is fundamental to rightsbased social protection (Chan, 2018). Social accountability, according to Ayliffe et al., (2018:7), includes the elements such as citizen action (voice), state-action, information, interface, and civic mobilisation.

The Social Protection Act 2075 and Regulation 2076 of Nepal have provisions for complaints from beneficiaries and anybody about social protection (section 22 and section 20) who can submit his/her complaints to the judicial committee of the local government. However, there is no provision for citizenstage interface mechanism. Likewise, children are not considered as key stakeholders, and do not have provision for them to participate in any level of social protection management committee, policy formulation, monitoring and evaluation mechanism.

\subsubsection{Governance and institutional capacity}

Sufficient institutional capacity, and clear internal rules, regulation, reporting mechanism, and operating procedures.

The Government of Nepal has been progressive in terms of improving governance system to build its institutional capacity required for social protection. A separate department - National Identity Card and Civil Registration Department - has been established to manage non-contributory social protection scheme. The department is dedicated to establishing a national level robust online Management of Information System, and an established banking payment system to reduce all forms of leakage and ensure effective delivery of the service. The department is constantly engaged in building capacities of municipalities and ward officers.

Social protection in Nepal is regarded as an important part of policies aiming to reduce poverty and inequality, wherein it has been acknowledged for what is achieved so far. The drafting of the social protection framework and existence of a wide set of government-owned programmes across the lifecycle is a testimony, making Nepal a frontrunner in the region. Despite this positive trend, social protection in Nepal suffers from challenges at the institutional and administrative level. These include lack of strong leadership and coordination, proliferation of, and fragmentation between, programmes, and budget and capacity constraints. This undermines the effectiveness of social protection in general and for children specifically (IDS, 2016:35).

Ward offices, health posts and schools are an important platforms to deliver social protection programme in Nepal, though they still lacking adequate human resources, equipment and trainings and coordination. National framework for social protection is still in the draft phase and has remained as such for a decade. There is no systematic, strategic vision and guiding framework to regulate the social protection programmes at the local level.

\subsubsection{Financial and fiscal sustainability}

Statistics shows that about 68 per cent of the total social protection budget (cash transfer) is spent on pensions and allowances, 29 per cent on assistance allowances and three per cent on scholarships. According to the Economic Survey 2019/20 of the Ministry of Finance, about NRs. 72.8 billion was allocated for social assistance (cash transfer to senior citizen, single women, persons with disabilities, endangered communities, and child nutrition grant), and there were about NRs. 3.2 billion allocated for various scholarships. It is apparent that of all social protection allowance, the government spends 65 per cent or more on senior citizens (including health allowance), 24.5 per cent on single and widow allowance, 4.5 per cent on disability allowance, 1.2 per cent on 
endangered community allowance, and 4.8 per cent on child nutrition allowance. From the endangered community allowances, children's share comes to be merely 2.4 per cent. Out of this, the share of children from the support allowance group will be up to 7.2 per cent on top of scholarships. Currently, children with complete disabilities and children of endangered group get NRs. 3,000/ month followed by children with disabilities NRs. 1,600/month, child nutrition grants NRs. $400 /$ month and birth registration incentive of NRs. 1,000.

Looking at the various types of cash transfers (monthly allowances) currently being provided, the cost for the financially inactive citizen is actually considered as an expenditure, while the cost for the child is an investment in terms of future human capital development. It has become imperative today to increase the share of child-oriented social protection in the total amount of assistance allowance, that is stated under the social protection scheme. This should be based on the needs and protection of the children. Moreover, the contribution of the federal, provincial and local level government in this work should be mainstreamed.

The Government of Nepal is planning to increase the budget for social protection to 13.7 per cent by 2025 . With this, about 60 per cent of the citizens will be covered by the social protection floor (NPC, 2019:228). Slowly it can be governed by the national social protection framework but would become a huge obligation for the government. The Government of Nepal is planning to make social protection universal at least to reach out to as much people as possible through its social protection floor. It requires huge budget, which in reality, is impractical. Once these programmes are launched, it is politically impossible to pull them back. So, the Government of Nepal has to initially introduce the national framework, and review the current social protection system before moving ahead, in addition to designing strategies to ensure its sustainability.

\subsubsection{Coherence and integration}

The Government of Nepal has made substantial improvements in the Constitution, laws and policies, institutional structures, plans and programmes in terms of ensuring the rights of children as a part of fundamental rights (NCRC, 2019). The National Child Right Council has been established under the Child Act 2018 to monitor the child rights situation in Nepal. The council has been actively coordinating and collaborating with various government agencies, development partners, non-governmental organisations, civil societies, and media for the wellbeing of children. In terms of the annual budget allocation for children under social protection, there has been a significant increase in the past few years. It shows that the Government of Nepal is sensitive towards the children in need of special protection from the state.

However, in regard to the coherence and integration, there is no comprehensive policy on overall transfers which could also comprehend social security and protection related issues more judiciously (Khanal, 2013). Lack of coordination was found to be a fundamental shortcoming to the functioning of Nepal's social protection system in addition to lack of a monitoring and regulating body that could provide guidelines, advice and regulations. A large number of ministries operate their own parallel programmes and distribution systems without cross-linkages (IDS, 2016:35). For example, mid-day meal is implemented by schools and is not coordinated with the health posts. Similarly, child grant is implemented by ward offices which requires birth registration certificate, but child grant is not coordinated with birth centers that can complement each other to ensure better results. Likewise, in regards to the scholarship schemes, its distribution is not functioning in an integrated manner; it is rather functioning 
in a scattered way, and there are variations in terms of scholarship distribution process from school to school, district to district and little internal coordination between different sections of the District of Education (DoE) responsible for scholarship distribution exists (Kafle, 2018: 2-3)

It has been observed that the role of the provincial government to implement the federal government funded social protection programme is not clear. The federal government is directly releasing budget to local governments and reporting system does not involve the provincial government. Some provincial governments have announced the new schemes like Beti Bachau Beti Padhau $(B B B P)$ in Province 2, Bank Khata Chhoriko, Surakchhya Jivan Bhariko in Karnali Province, Cash Transfer for Orphan Children in Bagmati Province, while none of these are linked with the existing social protection system.

\subsubsection{Responsiveness}

Social protection is a major approach to build people's resilience to cope with the consequences of both natural and man-made disasters. Thus, social protection system should be flexible and adaptive in response to the changing needs of the citizens in both normal and humanitarian situations. Especially, children need such flexible and adoptive social protection system since they are the most affected from external shocks. When a crisis hits, effective social protection support is often a crucial factor in determining whether children can quickly return to normalcy or their life paths will be permanently altered (UNICEF, 2019). Due to its location and variable climatic conditions, Nepal is one of the most disaster-prone countries in the world. Every year, disasters result in loss of life and damage to properties (ECHO Factsheet Nepal, 2019) and the Government of Nepal has come through rigorous response process that includes different forms of social protection programme such as cash transfer, in-kind support, livelihood supports, and stipend for the children. However, existing legal documents show that there is a lot to be done in linking social protection with disaster reduction management. Such as Article 43 of the Constitution confines its constitutional guarantee to social protection to certain groups of citizens (Government of Nepal 2015:105). However, despite the fact that disaster affects all citizens and not merely those enumerated by the article, the Social protection Act is silent on supporting the disaster affected citizens. Similarly, the Disaster Reduction and Management Act 2017 is the fundamental legislative policy to reduce and manage disasters in Nepal. The Act's preamble limits its objectives to protecting human lives, private and public property, natural and cultural heritages, and physical infrastructures. Empowering disaster vulnerable and affected people through building their resiliency is not reflected in the Act. It could perhaps be due to lack of national framework on social protection that would guide the linkage and integration of the social protection strategies with disaster risk reduction and management programmes and policies. Nevertheless, need for improvement in monitoring and evaluation system for social protection has been realised specially to respond to the need of children, though very few studies on social protection have been done from the children's perspective.

There are some issues and challenges in making the existing social protection programmes more child sensitive. Among others, share of social assistance (cash transfer) that should be increased for children and mainstreaming to one system; developing or widening fiscal space for sustainability; developing transparent mechanism in all three-tiers of the government; improving information management system that should be well informed to all service delivery 
mechanism as well as to all beneficiaries; improving system to categories needy beneficiaries; developing capacity of service providers in beneficiaries' rights perspective are some of the issues pertinent to the social protection programmes in Nepal.

\section{Conclusion}

The Government of Nepal seems to be sensitive towards children and has been increasing its investment in children focused programmes every year. The government has realised the importance of investment in early age of children to tap 'short window of opportunity'. However, the children's share is still very low in comparison to other social protection targeted at the adults. The 'children who needs special protection from state' as defined by the Child Act 2018 are excluded from the social protection programme of the state such as orphan children, street children, HIV AIDs affected children and so on. Therefore, inclusion of these categories of children still needs to be improved. Secondly, social protection has been one of the priority areas of the state, wherein 3.5 per cent of the Gross Domestic Product (GDP) accounting to 11 per cent of the total budget is invested for social protection. This includes different forms of social protection such as social insurance, social assistance, social services, social funds and labor market. Accordingly, laws, policies and programmes are implementated by categorising social protection as contributory and noncontributory in nature.

The state is focusing on increasing contributary social protection to improve fiscal space and social protection programmes. These are quite popular among citizens, however there is lack of coordination, integration and complementation among ministries, and conceptual confusion and linkages among programmes. This can be attributed to absence of a comprehensive framework or directive at the federal level. Social accountability mechanisms are not prioritised, and thus participation of children and their parents/caregivers as right holders in the designing and implementation phase is lacking. There is no practice of periodic monitoring and evaluation of the programme to know the impact, adequacy, and appropriateness for children. Thus, the Government of Nepal has to evaluate the existing social protection programmes focusing on the effectiveness, efficiency, impact and sustainability primarily from a child sensitive perspective. The government appears to be serious about the governance in social protection, and so has been investing in digitization of data, establishing and strengthening online reporting system, and initiating banking payment among others. Moreover, the information management system should be comprehensive, integrated, and linked with different departments and ministries to augment the overall impact in the lives of children.

\section{References}

Ayliffe, T., Schojødt, R., \& Aslam, G. (2017). Social accountability in the delivery of social protection - Literature-Review. Working Paper, Development Pathways https://socialprotection-humanrights. org/wp-content/uploads/2017/12/SocialAccountability-Literature-Review.pdf accessed on 9 September 2020.

Ayliffe, T., Schojødt, R., \& Aslam, G. (2018). Social accountability in the delivery of social protection: Technical guidance note, https://socialprotection.org/discover/ publications/social-accountability- 
delivery-social-protection-technicalguidance-note accessed on 12 September 2020 .

CEDA. (2017). Impact study of social assistance (Cash Transfer). Kathmandu: The Department of National ID and Civil Registration (DoNIDCR) and Save the Children.

Chan, A. (2018). Social accountability in social protection: Unpacking concept. https:// socialprotection.org/es/discover/blog/ social-accountability-social-protectionunpacking-concept accessed on 26 January 2018.

ECHO Factsheet - Nepal. (2019). Factsheet - Nepal (May, 2019). https://reliefweb.int/report/ nepal/echo-factsheet-nepal-may-2019 accessed on 10 October 2020.

Economic Policy Research Institute. (2020). Nepal child grant programme early evaluation report. Kathmandu: United Nations International Children's Emergency Fund (UNICEF).

Global Coalition to End Child Poverty. (2017). Childsensitive social protection. Briefing Paper. https://resourcecentre.savethechildren. net/publishers/global-coalition-end-childpoverty, accessed on 1 September 2020

Government of Nepal. (2015). The Constitution of Nepal (2015). Kathmandu: Government of Nepal.

IDS. (2016). Improving social protection's response to child poverty and vulnerability in Nepal: Policy Brief. Kathmandu: Save the Children.

ILO. (1952). C102 - Social Security (Minimum Standards) Convention, (No. 102). International Labour Organization. http:// www.ilo.orghttps://www.ilo.org/dyn/ normlex/en/f?p=NORMLEXPUB:12100:0:: NO::P12100_ILO_CODE:C102 accessed on 30 September 2020
Kafle, B. (2018). A study on the effectiveness of the scholarship provided at school level and identification of measures for its improvement. Kathmandu: Vertex Consult Pvt. Ltd. http://www.doe.gov.np/assets/ uploads/files/0abf8e 73c50b2cca90dc 2b43e2eeb848.pdf accessed on 10 September 2020.

KARRAK Enterprise Development Services Private Ltd India and Valley Research Groups Nepal. (2010). A study on understanding the scope of social protection measures as a means to improve child wellbeing in Sindhupalchowk, 2010. Kathmandu: Save the Children.

Khanal, D. (2013). Social security/social protection in Nepal: Situation analysis. Kathmandu: International Labour Organization ILO, Nepal.

Ministry of Education. (2016). Status report, 2016. Kathmandu: Ministry of Education, Government of Nepal.

NCRC. (2019). State of children in Nepal. Kathmandu: National Child Right Council, Government of Nepal. Nepal https://www.ncrc.gov.np/accessed on 17 October 2020

New ERA Nepal. (2017). Nepal demographic and health survey. Kathmandu: Ministry of Health, Nepal https://www. dhsprogramme.com/pubs/pdf/fr336/ fr336.pdf accessed on 30 September 2020 .

Niti Foundation. (2019). Policy landscape of social protection in Nepal. Kathmandu: Niti Foundation.

NPC. (2018). Nepal multidimensional Poverty Index: Analysis towards action. Kathmandu: National Planning 
Commission, Government of Nepal.

NPC. (2019). The Fifteenth National Plan (20192024), Approach Paper. Kathmandu: National Planning Commission, Government of Nepal. https://www.npc.gov. $\mathrm{np} / \mathrm{np} /$ category/periodic_plans accessed on 27 October 2020

NPC. (2020). Nepal: National review of sustainable progress report. Kathmandu: National Planning Commission, Government of Nepal.

OHCHR. (1990). UN Convention on the Rights of the Child (UNCRC). Office of the United Nations High Commissioner for Human Rights. https://www.ohchr.org/Documents/ Professionalinterest/crc.pdf accessed on 30 October 2020.

Oxford Policy Management. (2020). Coverage of social security allowance in areas at risk of floods and droughts, Nepal. Kathmandu: Oxford Policy Management accessed on 29 September 2020.

Roelen, K., \& Sabates-Wheeler, R. (2012). A child sensitive approach to social protection: Survey practice \& strategic needs, Journal of Poverty and Social Justice, 20(3): 291306.

Sanfilippo, M., de Neubourg, C., Martorano, B. (2012). 'The Impact of Social Protection on Children: A Review of the Literature', Working Paper 2012-06, UNICEF.

Save the Children. (2014). Programing in Child Rights Governance: A Technical Guide for Practitioners, p. 40. Save the Children.

Save the Children. (2015). Child-sensitive social protection, position paper (November 2015). Save the Children. https://resourcecentre. savethechildren.net/node/12240/pdf/cssp position_paper_english.pdf, accessed on 1 September 2020.
Save the Children. (2020). Analysis of child-sensitive social protection in Malawi, https:// resourcecentre.savethechildren.net/library/ analysis-child-sensitive-social-protectionmalawi, accessed on 2 September 2020.

Save the Children. (2020). Child Sensitive Livelihoods, https://onenet.savethechildren. net/whatwedo/Child_Poverty/Pages/ChildSensitive-Livelihoods.aspx accessed on 12/31/2020SPCSN (2016), Three-Years Strategic Plan (2016-2018), accessed on 2 September 2020.

Save the Children. (2020). Global Child Sensitive Social Protection Approach Paper, https:// resourecenter.savethechildren.net p.2-8 accessed on 4 September 2020.

UNICEF. (2007). UN General Assembly adopts powerful definition of child poverty. United Nations International Children's Emergency Fund https://www.unicef.org/ media/media_38003.htm accessed on 24 September 2020.

UNICEF. (2009). "Joint statement on advancing child-sensitive social protection" p.2. United Nations International Children's Emergency Fund.

UNICEF. (2014). A toolkit for assessing child sensitivity in social protection: A_toolkit_ for_social_transfers. United Nations International Children's Emergency Fund.

UNICEF. (2019). Programme guidance: strengthening shock pesponsive social protection system, 2019. United Nations International Children's Emergency Fund. https://www. unicef.org/media/63846/file accessed on 3 September 2020. 
